Bulgarian Academy of Sciences. Space Research and Technology Institute.

Aerospace Research in Bulgaria. 33, 2021, Sofia

DOI: https://doi.org/10.3897/arb.v33.e05

\title{
LAND COVER AND LAND USE CHANGE IN KARST REGION DEVETASHKO PLATEAU
}

\author{
Georgi Jelev ${ }^{1}$, Dilyana Stefanova ${ }^{2}$, Petar Stefanov ${ }^{2}$ \\ ${ }^{1}$ Space Research and Technology Institute - Bulgarian Academy of Sciences \\ ${ }^{2}$ National Institute of Geophysics, Geodesy and Geography - Bulgarian Academy of \\ Sciences \\ e-mail: g_jelev@abv.bg,dili_stefanova@abv.bg,psgeo@abv.bg
}

\section{Land Cover}

Keywords: Land Cover, Land Use, Karst, Karst Geosystems, Devetashko Plateau, Corine,

\begin{abstract}
The Corine Land Cover (CLC) is a digital data about land cover, which is distributed into 44 classes, whereas for the territory of Bulgaria the CLC classes are 36. The minimal mapping unit is 25 hectares (for 2D objects and $100 \mathrm{~m}$ for linear objects). Data sets for the years 1990, 2000, 2006, 2012, and 2018 are available, as well as for the changes, which have occurred between each couple of years (1990-2000, 2000-2006, 2006-2012, and 2012-2018).

The great data sets provide to track over a nearly 30-year period of land cover changes in model karst regions, which are strongly vulnerable to anthropogenic and natural influences.

This paper considers the changes in the land cover types on the Devetashko plateau - a typical karst plateau in North Bulgaria. Land cover and land use changes directly affect the processes of modern karst-genesis, the soil-vegetation cover, the quantity and quality of underground karst waters.
\end{abstract}

\section{Introduction}

Karst is a widely spread natural phenomenon with which the lives of millions of people are directly or indirectly related [1]. Karst territories are made of karst geosystems, which are characterised by the fact that they consist of clearly expressed underground (caves) and above-ground part that are closely related genetically and dynamically [2,3]. Karst geosystems feature high vulnerability and enhanced risk of influences, especially against the background of the increasingly expanding global changes. In Bulgaria, karst territories comprise $1 / 4$ of its area [4] and from specific living and economic activity environment for people who must consider its peculiarities on a daily basis. In addition, this puts forward on the agenda the urgent need of good knowledge of and compliance with karst specifics. This is the only way to achieve sustainable development of karst territories and to 
resolve successfully the topical social and economic problems during their handling and management.

The active processes occurring on a global and European scale since the end of the $20^{\text {th }}$ century affect the social and economic development of Bulgaria, as well. After 1989, many structural (with respect to ownership and production), technological and organizational reforms are ongoing, which affects all spheres of economic activity: industry, agriculture, services. After the passing of the Restoration of Land Ownership Act (1991) and with the start of the reform in 1992, minor owners and unemployed became predominant in the field of agriculture (as a result of the destroyal of the production structures existing before). The new users of the former publicly owned land became owners of agricultural land, tenants, the hired workforce, self-employed people, i. e. differentiation of economic interests occurred. Subsequently, access to European subsidies from the pre-accession funds and mostly, from the structural European funds in the field of agriculture, resulted in new changes in the use of agricultural land and the grown agricultural crops. These changes affect especially strongly the vulnerable karst territories. Changes in the development of agriculture and cattle breeding also occurred after the adoption of Natura 2000 and the application of the relevant environmental protection law.

Changes are also observed in the use of building material quarries, which are typical for karst territories. Some quarries are abandoned, but others are let on concession. New quarries are also developed.

The sequence of changes in land use strongly affects the fragile balance in karst geosystems. The role of anthropogenic pressure is of varying nature. For instance, incorrect agricultural practices in karst territories result in accelerated erosion and pollution of underground karst waters. This requires prevention and undertaking of urgent measures for the sustainable development of karst territories. These are also indispensable because of the depopulation of karst regions, which makes them socially unstable. At the same time, during the recent years, external users (tenants) are widely applying deep ploughing with heavy machines of the arable lands, including the lands that were neglected during the transition. The economic objectives of these land users are not always related to the ecological standards imposed by the karst specifics of the regions [5]. The consequences of the increasingly active manifestations of global climatic changes and the increasing number of extreme climatic events, especially torrential rains and quick snow melting, are not accounted for, either. On the karst terrains with shallow soils and numerous whirlpools and pot-holes, they cause accelerated erosion, especially for arable lands. This results in import and deposition of great quantities of solid (clayish) deposits in the underground cave systems (Fig. 3).

During recent years, karst territories with attractive forms are becoming an object of increasing interest for tourists and are turning into sports and leisure sites. [6-9]. They attract both organised, as well as unorganised tourists. Regretfully, tourist infrastructure in karst terrains is insignificant or badly designed and built, 
including the ecopaths to popular karst objects. These pose a number of risks for visiting tourists, with one lethal accident already recorded (Krushunska ecopath). The major reason is that the available ecopaths lack clear status and their handling and maintenance is not regulated by law. No control on the visits is exercised, including along the ecopaths in protected karst territories. This has often negative effect on karst objects, incl. pollution, knocking-off, scratching. However, karst territories will continue to be attractive tourist destinations with positive regional and local economic effects. The latter, however, is still weak because of the insufficient experience of local communities in tourist industry, on the one hand, and on the other hand - their insufficient knowledge of karst specifics.

All this requires, especially at the managerial level, a better understanding of the relations between the major activities in karst terrains, such as agriculture, mining, forestry, tourism and more. The long-term and short-term effects of these activities might have and have on karst environment and karst heritage should also be accounted for. It is also important to observe the changes in agriculture and to assess and forecast the consequences thereof in view of rational management and minimising the negative effects on biodiversity, health, and life of the population. In this relation, land cover changes are an important information source [10]. Within the earth surface monitoring service of the EU Copernicus Programme and under the guidance of the European Environment Agency under the Corine, land cover (CLC) Project, the vector layers with land cover types and their change with time are maintained and updated on a regular based on [11]. The major thesis of this publication is to determine the extent to which this information may be useful to analyse the changes in land use in a typical karst region. It tracks the land cover changes on the Devetashko plateau in Northern Bulgaria, which is a model region for multi-annual studies by the Experimental Laboratory of Karst Studies of the National Institute of Geophysics, Geodesy and Geography of the Bulgarian Academy of Sciences (NIGGG - BAS).

\section{Materials and Methods}

Using geographic information systems (GIS), the spatial distribution and quantitative characteristics of the land cover and land use (LCLU) classes of the Devetashko plateau are analysed.

During the conduct of this study, a GIS database was composed (KARST.gdb), with a set of vector and raster layers containing administrative boundaries (of districts, municipalities, lands/settlements' land-use areas (SLUAs) ${ }^{l}$, populated places and state boundary), water objects (lakes, dams, and river network), contour of the model regions, protected territories under Natura 2000

\footnotetext{
${ }^{11}$ Totality of the land properties belonging to a given settlement (i.e. the land properties both in the settlement and in the settlement's adjacent territory).
} 
(according to the Directive on birds, Directive on habitats), Corine land cover (CLC) under the Copernicus Programme, containing vector layers for 1990, 2000, 206, 2012, 2018, and the change of land cover (Corine, Land Cover Change, LCC) over the subperiods: 1990-2000, 2000-2006, 2006-2012, 2012-2018, digital elevation model (altitude belts) - ASTER Global Digital Elevation Model (GDEM) with spatial resolution of $30 \mathrm{~m}$.

Table 2. Nomenclature „, Corine, land cover", Level $1 \div 3$, Fig. $2 . \div 5$.

\begin{tabular}{|c|c|c|}
\hline Level 1 & Level 2 & Level 3 \\
\hline \multirow{3}{*}{$\begin{array}{l}1 \text { Artificial } \\
\text { surfaces }\end{array}$} & 11 Urban fabric & 112 Discontinuous urban fabric \\
\hline & $\begin{array}{l}12 \text { Industrial, commercial and } \\
\text { transport units }\end{array}$ & 121 Industrial or commercial units \\
\hline & $\begin{array}{l}13 \text { Mine, dump and } \\
\text { construction sites }\end{array}$ & 131 Mineral extraction sites \\
\hline \multirow{6}{*}{$\begin{array}{l}2 \text { Agricultural } \\
\text { areas }\end{array}$} & 21 Arable land & 211 Non-irrigated arable land \\
\hline & \multirow{2}{*}{22 Permanent crops } & 221 Vineyards \\
\hline & & 222 Fruit trees and berry plantations \\
\hline & 23 Pastures & 231 Pastures \\
\hline & \multirow[b]{2}{*}{$\begin{array}{l}24 \text { Heterogeneous agricultural } \\
\text { areas }\end{array}$} & 242 Complex cultivation patterns \\
\hline & & $\begin{array}{l}243 \text { Land principally occupied by } \\
\text { agriculture, with significant areas of } \\
\text { natural vegetation }\end{array}$ \\
\hline \multirow{6}{*}{$\begin{array}{l}3 \text { Forest and } \\
\text { semi natural } \\
\text { areas }\end{array}$} & \multirow{3}{*}{31 Forests } & 311 Broad-leaved forest \\
\hline & & 312 Coniferous forest \\
\hline & & 313 Mixed forest \\
\hline & \multirow{2}{*}{$\begin{array}{l}32 \text { Scrub and/or herbaceous } \\
\text { vegetation associations }\end{array}$} & 321 Natural grasslands \\
\hline & & 324 Transitional woodland-shrub \\
\hline & $\begin{array}{l}33 \text { Open spaces with little or } \\
\text { no vegetation }\end{array}$ & 332 Bare rocks \\
\hline $\begin{array}{l}5 \text { Water } \\
\text { bodies }\end{array}$ & 51 Inland waters & 512 Water bodies \\
\hline
\end{tabular}

Source: I.1., Elaboration: Georgi Jelev

The methods of spatial analysis and statistics in the medium of a geographic information system (GIS) were used. The data were processed within the boundaries of the Devetashko plateau and were matched at SLUAs level. The data are organised in a Pivot table and the spatial relationships between the land cover/land use types and their changes over the period 1990-2018 were studied. The period after 1990 was studied when the change of ownership and the 
restitution of agricultural land caused exceptionally serious changes in the organization of agriculture, too.

The spatial distribution and the quantitative characteristics of the presented land cover and land use classes were analysed at two levels: for the entire region of the Devetashko plateau and for groups of lands/SLUAs, falling within parts of municipalities which are included within the plateau's boundaries. The analyses were conducted at level 1 and level 3 of Corine land cover. Comparative analysis was also used. The transition from one land cover class to another over subperiods was also tracked.

\section{Devetashko Karst Plateau}

The Devetashko plateau $\left(343.08 \mathrm{~km}^{2}\right)$ is located between the valleys of the rivers Rositsa and Osam in the southern periphery of the Danube (Moesian) plane in Bulgaria. Its northern foot features altitude of $100 \div 150 \mathrm{~m}$ a.s.l. and is outlined by a clearly expressed fault area in the relief, and its southern foot features altitude of $350 \div 400 \mathrm{~m}$ a.s.l. and is not expressed clearly. The plateau-shaped ridge part varies between 350 and $450 \mathrm{~m}$ a.s.l. and is inclined to the north. The highest point of the plateau is the Chukata peak (558 $\mathrm{m}$ a.s.1.).

The Devetashko plateau is composed mainly of organogenic limes of Lower Cretaceous age (Apt-Urgon). They make up subhorizontal layers with a slight inclination to the north. The prevailing development of limes is the reason for which, on the plateau, classical karst of autochthonous type has developed, after [12], without permanently running river waters. In the relief, morphologic karst complexes of classical forms - surface and underground, dominate, with prevailing whirlpools and hollows/fif/ek their total number being several thousand. They are elements of well-differentiated karst geosystems whose exits are mostly on the northern slopes and the foot of the Plateau, which are marked by high-capacity karst springs and large entrances of spring caves. One of the most typical karst geosystems is the Kurshunska one $\left(43 \mathrm{~km}^{2}\right.$, located in the eastern part of the plateau), which since 1990 has been the model karst region of the Experimental Laboratory of Karst Studies of the NIGGG-BAS (Fig. 3).

Many of the plateau's pot-holes have been reshaped into precipices and precipice caves. Another part of the pot-holes has been tamponed (incl. by humans), with karst lakes and bogs formed around - one of the most typical in Bulgaria $[13,14]$. 


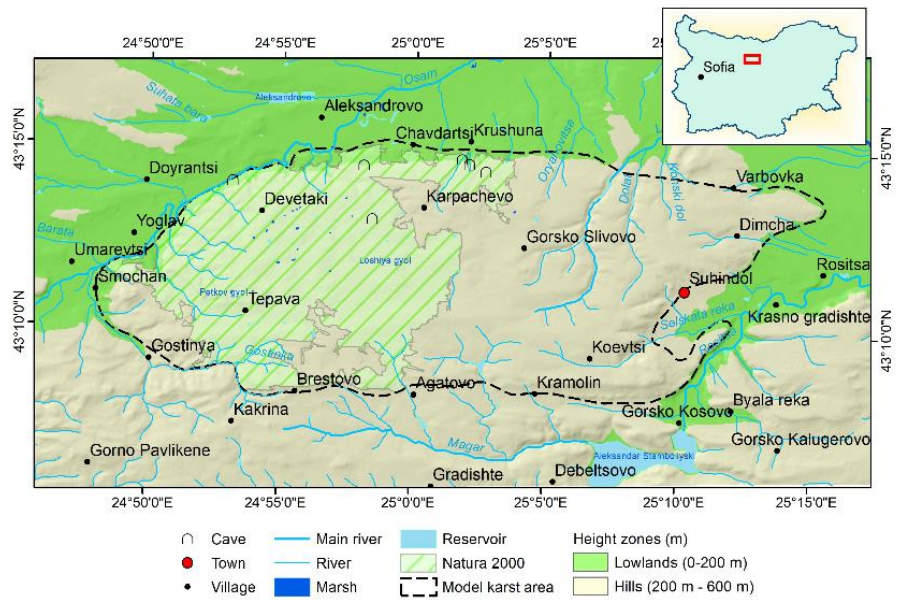

Fig. 1. Devetashko Plateau

Sources: Information System for protected areas according to ecological network NATURA 2000 [I.2.], Register of protected areas in Bulgaria, Executive Environment Agency - MOEW, Bulgaria: Digital Elevation and administrative data: The Study of Integrated Water Management in the Republic of Bulgaria. JICA; Field mapping of caves and dolines: P. Stefanov - unpublished paper ,Comparative geodynamics of karst geosystems in the Predbalkan and Western Rhodopes", Sofia, 1993, Institute of Geography-BAS. Drawn by Georgi Jelev

On the Devetashko plateau, 68 karst caves with a total length of about $18 \mathrm{~km}$ have been studied. The longest one is the water Boninska Cave (Popova cave) by the Krushuna village $-4530 \mathrm{~m}$, which is connected with the spring cave Vodopada (1995 m) - one of the longest water cave systems being studied in Bulgaria (above $6.5 \mathrm{~km}$ ). Some caves on the plateau are former objects of economic activity (the Chavdarska cave/Mandrata and the Devetashka cave - a former object of the army) or have been used for water supply. As tourism in the Devetashko plateau became more popular, 7 caves are already objects of nonregulated tourist activity. The most frequently visited one is the Devetashka cave where the greatest cave hall in Bulgaria has formed.
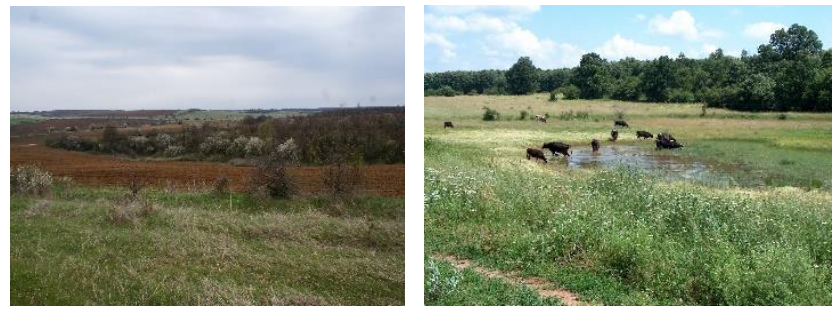

Fig. 2. Devetashko plateau - Landscape in the vicinity of Gorsko Slivovo village Photo: P. Stefanov 
The climate of the Devetashko plateau is moderately continental, with an average annual temperature about $10.5{ }^{\circ} \mathrm{C}$. In winter, the plateau-shaped part features temperature, which is by about $2{ }^{\circ} \mathrm{C}$ higher than the temperature of the north foot. During recent years, abrupt heatings have been observed even in February, which causes quick snow melting in the ridge parts (Fig. 3). The average annual amount of precipitation is between 650 and $700 \mathrm{~mm}$, with spring-to-summer maximum (May-June). About 33\% of the precipitation form underground water outflow, which is a typical karst. The biggest karst springs are concentrated in the northern periphery of the plateau (near-fault drainage system). Their waters are fresh, hydrocarbon-calcium. A typical feature of the underground karst waters is their strong vulnerability to pollution. Its sources are the non-regulated landfills in the widely spread whirlpools with active pot-holes, as well as the continuous anthropogenic loading (mainly agricultural) on the plateau's territory. The settlements located on the plateau lack sewerage systems and wastewater is not treated. Therefore, the abounding underground karst waters on the plateau are strongly polluted and the greatest part of them is not potable.

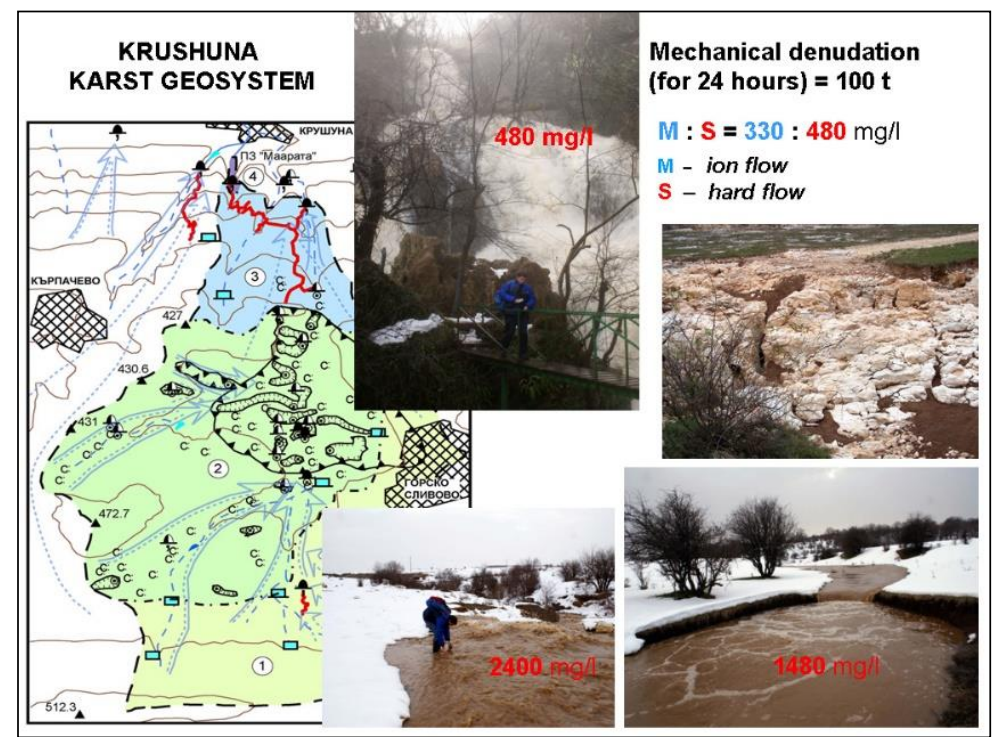

Fig. 3. Active mechanical denudation in the Krushuna karst geosystems in the Devetashko plateau resulting from intensive snow melting (February, 2012)

(archive of the Experimental Laboratory of Karst Studies of the NIGGG-BAS, Drawn by P. Stefanov)

The soil cover of the plateau is made of typical-for-Bulgarian-karst soil types [15], with prevailing luvisols (LV), rendzik, (LPk), and dystric (CLd) soils, developed in the foot of the Plateau and in the uvalas, hollows, and whirlpools. 
Albeit the karst terrain, the slightly sloped ridge parts are covered with a thick soil layer (mostly luvisols) where traditional agriculture is developing. The eroded arable lands and the slopes of the negative karst forms with karren fields are used as pastures. Cattle breeding in the Devetashko plateau has deep historical roots and with it, the artificial tamponing of whirlpools' pot-holes in which karst bogs and lakes where cattle drinks water have formed, is related. Calcic (GLk) soils have also formed there. During the dating of the depositions in Irmanov gyol, located westward of Gorno Slivovo village, it was established that the age of the bog is about

Three centuries [16]. The results from the palinologic studies show that grass vegetation with rich diversity of ruderal and anthropophyte types was dominant. They evidence of active anthropopressure - the palaeoecological circumstances have been favourable for development of agriculture and cattle breeding in the region.

The prevailing natural vegetation on the Devetashko plateau is broadleaved, mostly oak and Carpinus orientalis. Some limited areas have been artificially planted with coniferous forests. Part of the plateau's territory has been included in the ecological network Natura 2000. Two natural landmarks and six protected countryside with an area of 55.64 ha have been announced.

The arable land, which occupies a great percentage of the plateau's ridge part is attacked by accelerated erosion during torrential rains and especially, during active snow melting, when arable lands are most vulnerable to erosion. In addition, it is particularly active in the ploughed periphery of the whirlpools and hollows into which the generated snow water flows out. The ploughing applied by the tenants does not comply with the specifics of the karst relief and is carried out up to the edge of the whirlpools and hollows falling within the boundaries of the rented land. As a result, part of the soil is carried away through the underground karst systems and the springs that drain them. A typical example is the Krushunska karst geosystem (Fig. 3). During the observed active snow melting in February 2012, within $24 \mathrm{~h}$ only, about 100 tonnes of deposits (mostly at the expense of eroded ploughed soils) were carried away through the Vodopada karst spring, whereas 10 tonnes of them were deposited along the Krushunska travertine cascade proclaimed as natural landmark under the name „Maarata”.

The area of the Devetashko plateau includes, in whole or in part, 20 lands pertaining to five municipalities and three administrative regions (Fig. 4). On the territory of the Devetashko plateau and along its periphery, 15 settlements are located [2] (Fig. 4). The administrative partitioning of the Devetashko plateau poses significant risks for its management from the viewpoint of sustainable development. The reason for this lies in the lack of an integrated regional and sector policies, incl. in the field of agriculture, tourism, and other activities exercised on the plateau's territory. 
The population of the Devetashko plateau amounts to 5858 (2018). Over the period 1990-2018, the region has lost $45.50 \%$ of its population (Fig. 5). Ageing and depopulation are typical demographic processes of the plateau, which account for the old residential buildings, some of which have been abandoned and are crumbling down.

The economically active population is less than one-third of the overall active population. In some villages (Tepava, Devetaki, Brestovo, Gostinya and more), the economically inactive population exceeds $90 \%$.

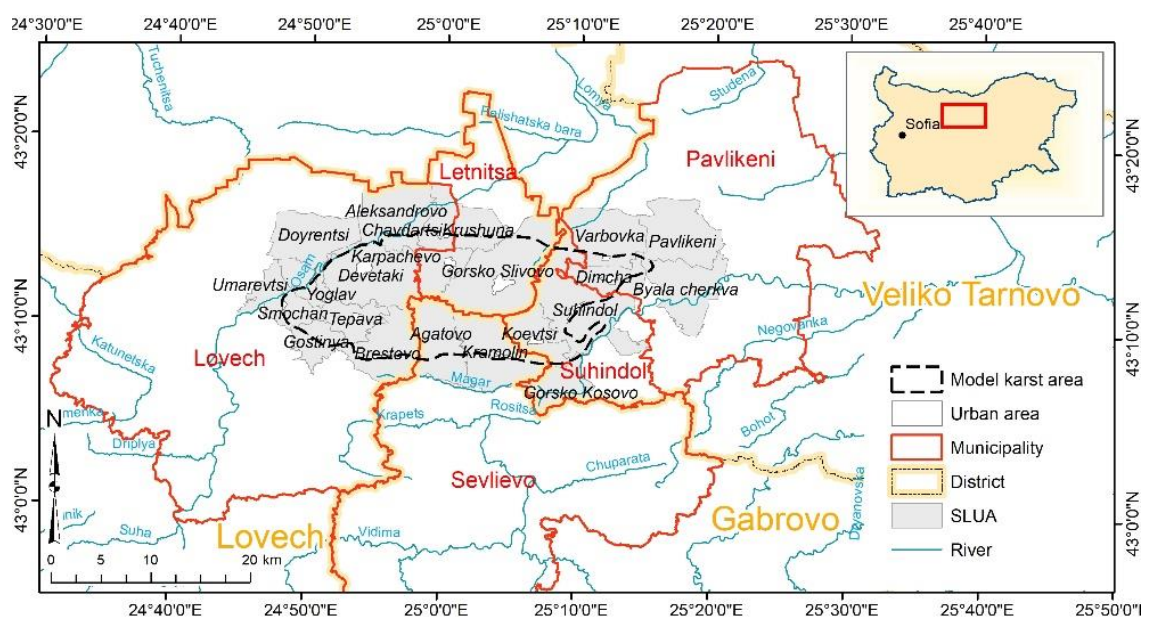

Fig. 4. Territorial and administrative location of the Devetashko plateau. Drawn by Georgi Jelev

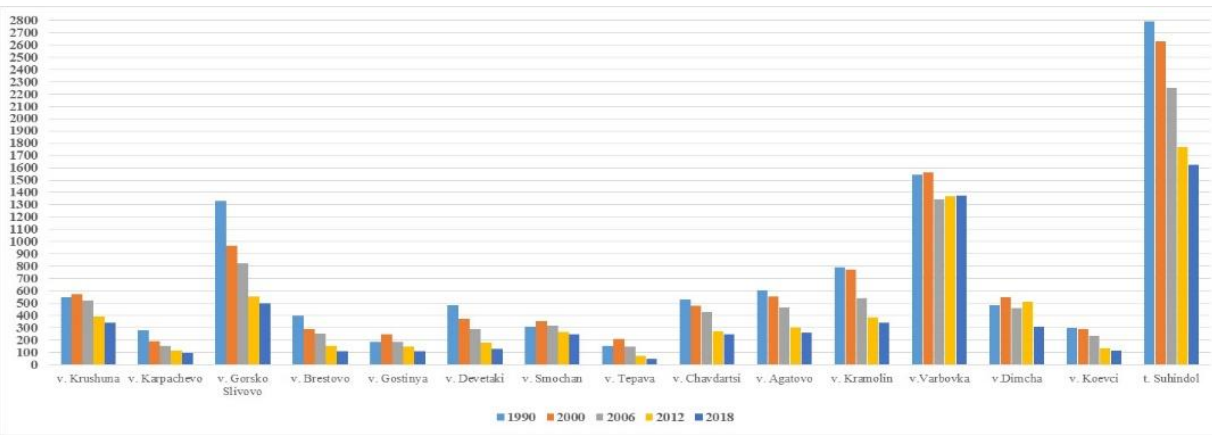

Fig. 5. Movement of the population by settlements on the territory of the Devetashko plateau over the period 1990-2018.

Source: NSI-Bulgaria, Elaboration: D. Stefanova 
On the territory of the Devetashko plateau, there are no industrial enterprises. Agriculture is the main developing economic activity which is exercised by tenant farmers and, to a lesser degree, by local users of agricultural land. EU subsidies for direct payments stimulate farmers to increase the area of the used agricultural land (UAL). Active activity is ongoing, aimed at changing the manner of the agricultural land's lasting use - more areas with cereals and less with orchards compared to the period up to 1989. The widest grown cereals are wheat and barley; in the gardens, they plant maize, sunflower, as well as plums, cherries, and peaches. Vines are traditionally typical for Suhindol and, to a lesser degree, for Krushuna. Because of the established system of middlemen of forest fruits, the growing of strawberries, raspberries, and blackberries is increasing steadily. A tendency for the restoration of the old orchards is also observed, due to the possibility to obtain additional agroecological payments [5].

Cattle's breeding is mostly related to the growing of cows, sheep, and goats, using the pastures in the karst terrains. It pertains to the small, mostly family sector, which provides no conditions to breed a large number of animals.

On the forest territory, apart from logging, a number of auxiliary uses are available - pasture of large and small cattle, collecting of hay from the bare areas, collection of leaf fodder. Herbs, forest fruits, mushrooms and nuts are also collected.

The Devetashko plateau provides possibilities for developing various forms of sport and tourism: ecotourism, educational tourism, and cultural tourism. Karst objects - caves and waterfalls, are attractive. Because of the low economic level of the settlements located on the Devetashko plateau and along its periphery, tourism in karst terrains is a good prospect for improving the life quality of the local communities. From this perspective, it is also possible to establish leisure and recreation territories.

The active social and economic changes in the Devetashko Plateau have also been reflected as land cover and land use changes, which, because of the specific karst territory, require analysis in three aspects - economic, social, and ecological.

\section{Results and Discussions \\ The overall review of Corine, land cover and land use on the territory of the Devetashko plateau}

On the territory of the Devetashko plateau, four land cover and land use classes have been observed after the CORINE nomenclature, level 1: artificial surfaces $\left(1^{2}\right)$, agricultural areas (2), forest and semi natural areas (3), and water bodies (5) over the whole observation period, 1990-2018 (Fig. 6). Of them,

\footnotetext{
${ }^{2}$ after the Corine, land cover nomenclature (Table 2)
} 
Artificial surfaces (1) feature the greatest area. This account for a little bit less than $60 \%$ of the plateau's area. Over the whole period, their share has been declining within the range $59.29 \%$ - 58.76\%, i.e. a tendency for a minor decrease by $0.53 \%$ is available. On the contrary, with Forest and semi natural areas (3), which come second by area, a tendency for a minor increase from $37.11 \%$ to $38.33 \%$ is observed. Ranking third by their share presentation are Artificial surfaces (1). With this class, the tendency is for a slight decrease, which starts from 2006, their share being preserved during the reporting years afterwards. Artificial surfaces (1) are mostly formed by class Discontinuous urban fabric (112) and, to an insignificant degree - by Industrial or commercial units (121) and Mineral extraction sites (131), (Fig. 6, Fig. 7). The identified change the identified change is mostly due to the depopulation of the Devetashko plateau and the scrambling of the abandoned anthropogenic infrastructure. The share of Water bodies (5) is less than one percent.

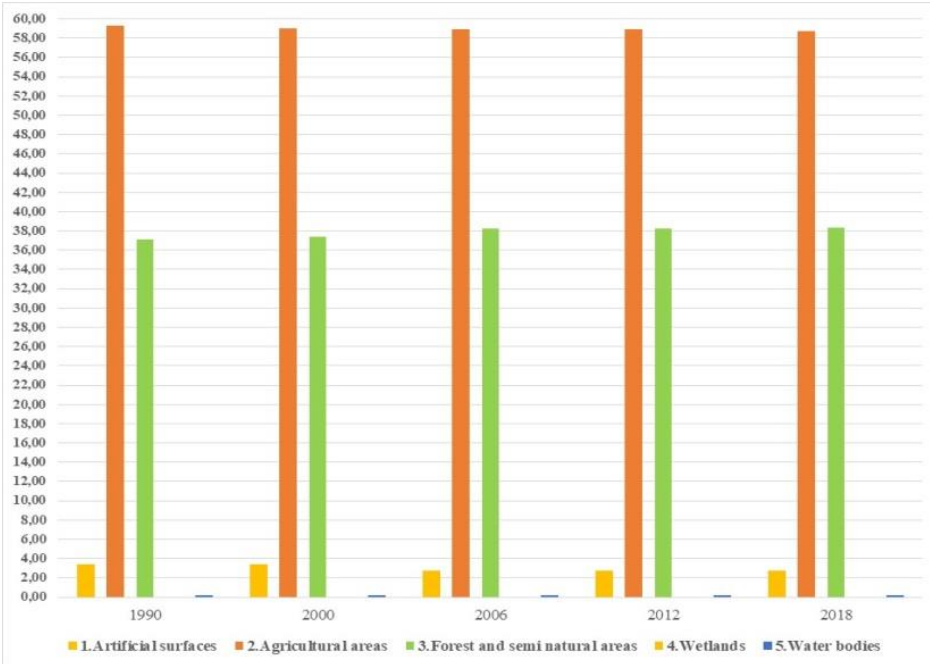

Fig. 6. Distribution and dynamics of Corine, land cover level 1 on the territory of the Devetashko plateau Source: [I.1.], Elaboration: D. Stefanova, G. Jelev

The analysis of Corine land cover level 1 demonstrates insignificant dynamics of the four major classes identified on the plateau. This means that it is mandatory to track the changes at lower levels so as to not ignore changes with effects of significance for the karst territory.

On the territory of the Devetashko plateau, four classes of Corine land cover and land use level 3 are observed (Fig. 7, Fig. 8). They are included in the above-mentioned classes at level 3 and are tracked for the years 1990, 2000, 2006, 
2012, and 2018. The review at this level reveals in greater detail the change, which is important to observe when accounting for potential negative impacts.

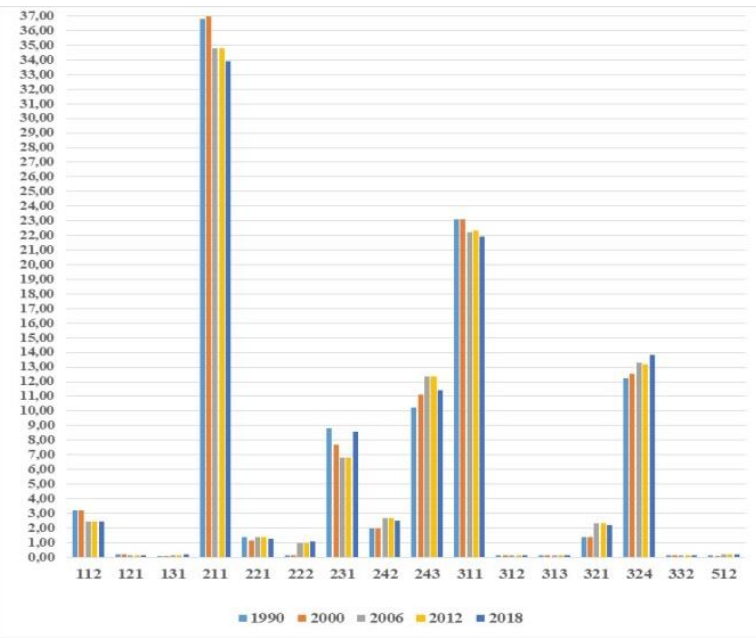

Fig. 7. Distribution and dynamics of Corine, land cover level 3 on the territory of the Devetashko plateau Source: [I.1.], Elaboration: D. Stefanova, G. Jelev

During the five observed years, Non-irrigated arable land (211) features greatest shares (above 33\%) of the plateau's territory. Irrespective of preserving its greatest shares with respect to the other classes, a tendency for declining by less than 3\% during the last year $(2018-33.90 \%)$ compared to the first year (1990 $36.78 \%$ ) (Fig. 7) is observed. Second, come Broad-leaved forests (311), which drop from $23.13 \%$ (1990) to $21.94 \%$ (2018) (Fig. 7). As of 2018, these two classes of Corine land cover level 3 occupy a bit more than half of the territory of the plateau, which makes them exceptionally important from the viewpoint of impact on the karst. Ranking third is the share of Transitional woodland-shrub (324) whereas, during the years, a lasting tendency for the shares' increase from $12.23 \%$ to $13.81 \%$ (Fig. 7) is observed. Featuring shares close to class (324) is class Land principally occupied by agriculture, which ranks third, with significant areas of Natural vegetation (243). It increases from $10.23 \%$ (1990) to $12.37 \%(2006,2012)$, after which it decreases to $11.39 \%$ (2018) (Fig. 7).

The shares of class Pastures (231) are also significant, which change over the years within the range 7\%-9\% (Fig. 7). Their change is closely related to the development of cattle breeding on the territory of the plateau, which, after 1989, was strongly affected by the social and economic changes in the country and, more specifically, with those in agriculture. The shares of class Complex cultivation patterns (242) (Fig. 7) also increase, which is related again with the changes in 
agriculture and the reinstitution of land in actual boundaries to its owners. The other presented classes (Fig. 7) feature insignificant shares, but irrespective of this, the change therein may also produce some negative impacts on karst.

From the viewpoint of the performed analysis, the changes related to the transition of one class into another in Corine land cover (Fig. 9), are interesting, as well.

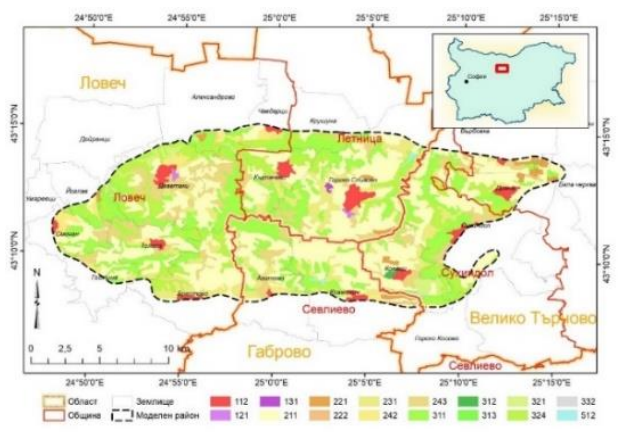

a) 1990

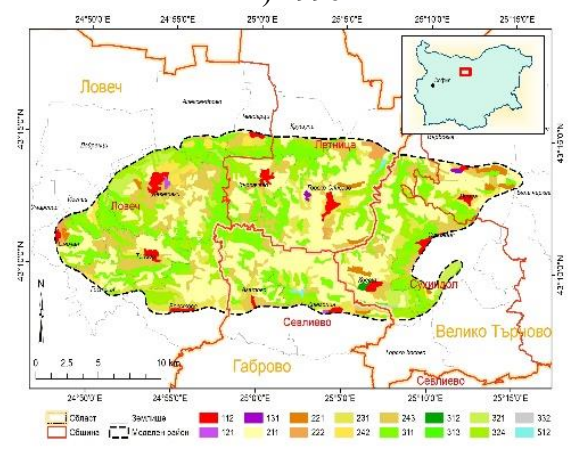

c) 2006

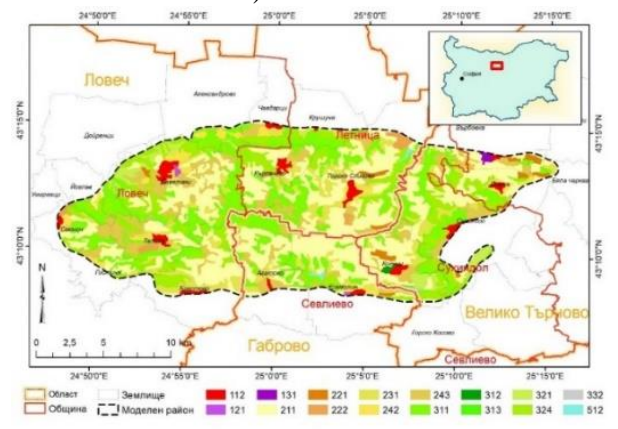

e) 2018

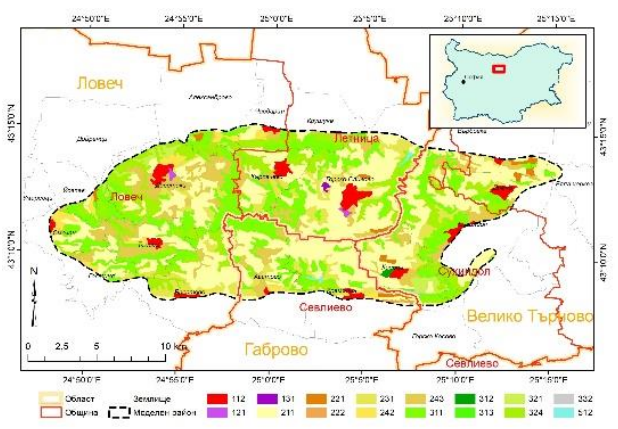

b) 2000

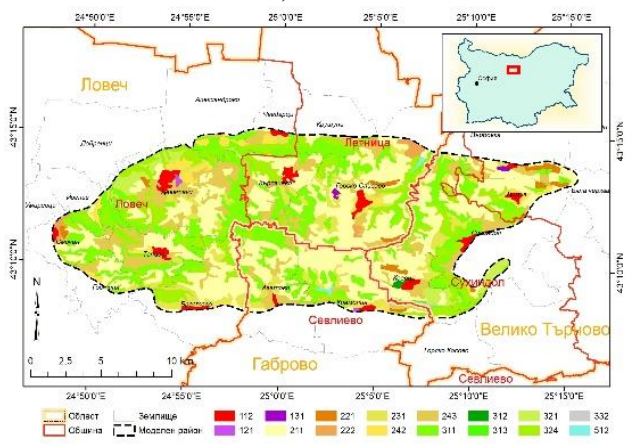

d) 2012

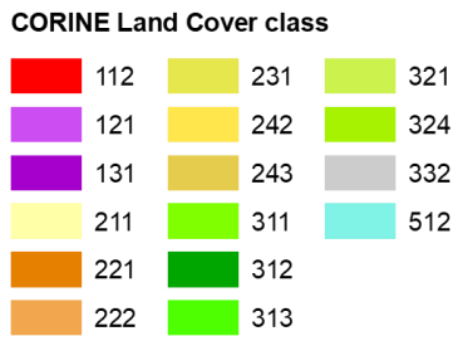

Fig. 8. Territorial distribution of Corine, land cover (CLC) level 3 (classes, Table 1) of the Devetashko plateau Source: Drawn by G. Jelev 


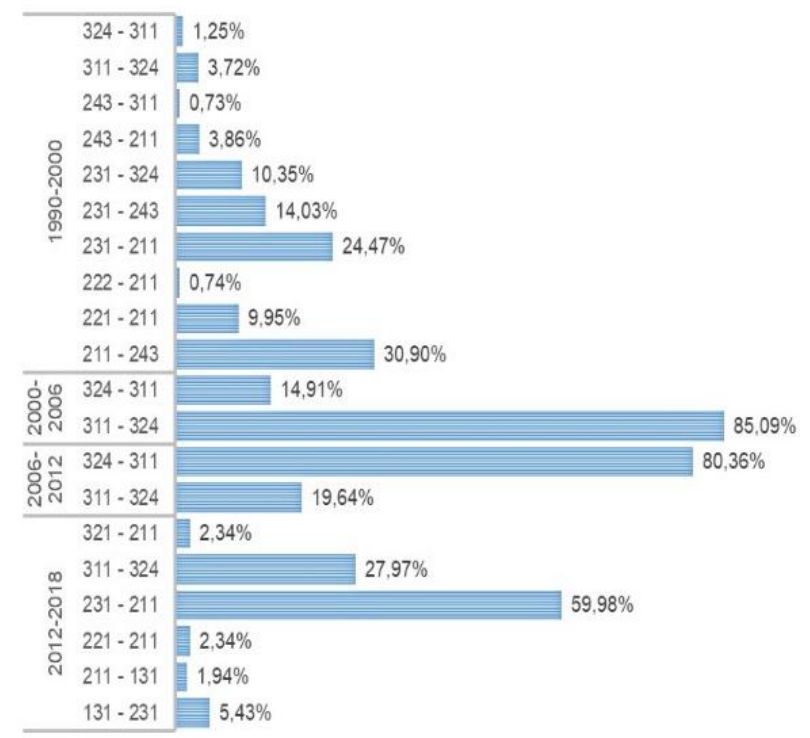

Fig. 9. Land cover change for the considered subperiods Source: [I.1.], Elaboration: G. Jelev

The greatest number of changes of one class into another are effected in sub-period 1990-2000, predominantly for 7 classes of agricultural areas (2) (Fig. 9, Table 1), logically following the economic changes in the country. A significant share of the changes over this time interval $(30.90 \%)$ is related to the transition of Non-irrigated arable land (211) into Land principally occupied by agriculture, to significant areas of natural vegetation (243). Another nearly one-fourth of the changes are affected by Pastures (231) turning into Non-irrigated arable land (211). Changes from Pastures (231) to Land principally occupied by agriculture, with significant areas of natural vegetation (243) and Transitional woodland-shrub (324) are also observed. Overall, most strongly affected are Pastures, of which a total of $44.85 \%$ have been transformed into other classes over this period. Vineyards (221) and Fruit trees and berry plantations (222) also lose areas, passing to Non-irrigated arable land (211). In conclusion, this sub-period is characterised by exceptionally great dynamics within Agricultural areas (2) (Fig. 9, Table 1).

During the next sub-period, 2000-2006, the changes are only in Forest and semi natural areas (3) and they are related to transition of Broad-leaved forest (311) into Transitional woodland-shrub (324), which accounts for $85.90 \%$ of the change. The other $24.91 \%$ of the changes over the period are in the reverse direction - from (324) to (311) (Fig. 9, Table 1). 
During the third sub-period, 2006-2012, the changes are again in Forest and semi natural areas (3) between classes (311) and (324), but the difference lies in the fact that now the greater share of the change $(80.36 \%)$ is oppositely directed, from Transitional woodland-shrub (324) to Broad-leaved forest (311) (Fig. 9, Table 1).

During the last sub-period, 2012-2018, the greatest share of the changes $(64.26 \%)$ comprises three classes of Agricultural areas of Corine, land cover (Fig. 9, Table 1). Most significant are the changes in Pastures (231), the greatest share being occupied by the transition into Non-irrigated arable land (211). The changes in Forest and semi natural areas (3) are also significant. They comprise Broad-leaved forest (311) and Natural grasslands (321). A greater share for the subperiod is characteristic of the transition of Broad-leaved forest (311) into Transitional woodland-shrub (324) $-27.97 \%$.

In relation to the karst plateau, the changes related to the transition of Nonirrigated arable land (211) into Mineral extraction sites (131) deserve particular attention.

\section{Review of CORINE, land cover and land use by types of SLUAs within the boundaries of municipalities falling within the territory of the Devetashko Plateau}

The Devetashko karst plateau is managed by different municipal administrations (Fig. 4). Because of the specifics of karst geosystems, the handling and use of the land require integrated management approach. In this sense, the observation of changes in land cover/land use types by groups of the SLUAs within the boundaries of the municipalities falling within the territory of the Devetashko plateau provides information which may be used in the development of ecological assessments and policies for local development and planning.

\section{Lands from the Municipality of Letnitsa (Lovech District)}

The lands of the villages from the Municipality of Letnitsa (Lovech District), which fall within the plateau's boundaries, are located mostly in the planar ridge part (Fig. 4). The SLUAs of Gorsko Slivovo and Karpachevo villages are included in whole, and the land of Krushuna village is included in part. Their total area amounts to $84.53 \mathrm{~km}^{2}$ or $24.64 \%$ of the plateau's territory. The population of the three settlements amounts to 934 people (2018). The drop in the population compared to 1990 (2158 people) is $56.72 \%$ (Fig. 5). The major economic activities are farming (agriculture and cattle breeding) and tourism.

This part of the plateau houses one of the most typical karst geosystems the Krushunska geosystem (area of $43 \mathrm{~km}^{2}$ ) (Fig. 3). Of the surface karst forms, whirlpools prevail, their number only in the karst geosystem being 379 . 
Based on the performed analysis, in this group of SLUAs at CORINE level 1, Agricultural areas (about and over 60\%), Forest and semi natural areas (about $1 / 3$ of the total area), and with insignificant shares - Artificial surfaces and Water bodies (Fig. 10a) are identified. The share distribution is preserved until 2000, and since 2006, changes occur in the first three classes at this level. Artificial surfaces have dropped by about $2 \%$. Agricultural areas display a tendency of gradual weak increase during the next years, and Forest and semi natural areas display the opposite tendency - insignificant drop during the next two observed years followed by an insignificant increase during the last year, 2018.

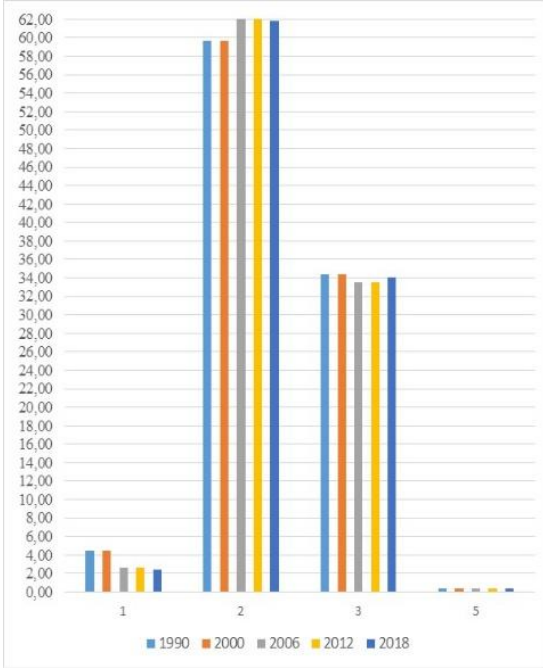

a)

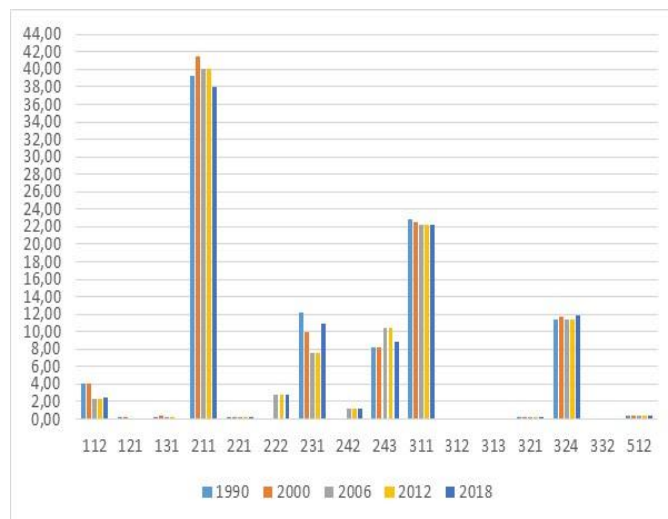

b)

Fig. 10. Land cover changes (classes, Table 1) in a group of SLUAs from the Municipality of Letnitsa falling within the territory of the Devetashko plateau (\%): a) (Level 1); b) (Level 3)

Source: [I.1.], Elaboration: D. Stefanova, G. Jelev

At CORINE level 3 on the lands of the Municipality of Letnitsa, changes in the number of presented classes are observed over the years. For 1990 and 2000 they are 11, in 2006 and 2012 they increase to 12, and in 2018 they are 11 again (Fig. 10b). With respect to the plateau as a whole, on these lands, the classes Coniferous forest (312), Mixed forest (313), and Bare rocks (332) are lacking - all of them pertaining to the Forest and semi natural areas. In the beginning of the period, Fruit trees and berry plantations (222) and Complex cultivation patterns (242) from Agricultural areas are also lacking, which is closely related to the changes in agriculture and their specific impact on these territories. The other absent classes at the end of the period, and more specifically, Industrial or 
commercial units (121) and Mineral extraction sites (131) refer to Artificial surfaces.

The typical thing about the lands of the Municipality of Letnitsa is the exclusively great shares of Non-irrigated arable land (211), followed by Broadleaved forest (311) (Fig. 10b). Transitional woodland-shrub (324), Land principally occupied by agriculture, with significant areas of natural vegetation (243) and Pastures (231) feature approximately equal shares within the limits of up to $12 \%$. Another characteristic is the dynamics of the changes in the shares within Agricultural areas where decreases and increase alternate.

\section{Lands from the Municipality of Lovech (Lovech District)}

The SLUAs from the Municipality of Lovech (Lovech District), which falls within the boundaries of the plateau, include in whole the SLUAs of Devetaki and Tepava villages and partially, the lands of another seven villages (Fig. 4). Their total area amounts to $126.93 \mathrm{~km}^{2}$, or $37 \%$ of the plateau's area. The population numbers 891 people (2018). The drop of the population compared to 1990 (2072 people) is $57 \%$ (Fig. 5). This is the most depopulated part of the plateau. In economic aspect, mainly agriculture and forestry are presented. In the northern part, the Devetashka cave is located, which is a landmark and has been turned into tourist attraction.

On the SLUAs from this Municipality, in contrast to the Municipality of Letnitsa, relatively close shares of Agricultural areas and Forest and semi natural areas (Fig. 11a) are observed. The changes in both classes at level 1 are insignificant, with alternating drops and increases. Class Water bodies (512) is absent, and class Artificial surfaces retain exclusively low values during the whole observed period.

At CORINE level 3, changes in the number of presented classes over the years are also observed. For 1990 and 2000 they are 10, and after 2006 they increase to 11 (Fig. 11b). The classes permanently lacking on the plateau as a whole are Mineral extraction sites (131), Coniferous forest (312), Mixed forest (313) and Bare rocks (332), all of them pertaining to Forest and semi natural areas. For the beginning of the period 1990-2000, absence of areas with Fruit trees and berry plantations (222) is identified.

About $50 \%$ of the areas are distributed between Non-irrigated arable land (211) and Broad-leaved forest (311), with their values tending to become equal as of the end of the period (Fig. 11b). Agricultural areas are supplemented by Land principally occupied by agriculture, with significant areas of natural vegetation (243) and Pastures (231), with shares of varying dynamics ranking between 6\% and $8 \%$. Forest and semi natural areas supplements its shares mainly by Transitional woodland-shrub (324), which features almost constant values 
(Fig. 11b). The changes in the classes pertaining to Agricultural areas are more obvious.

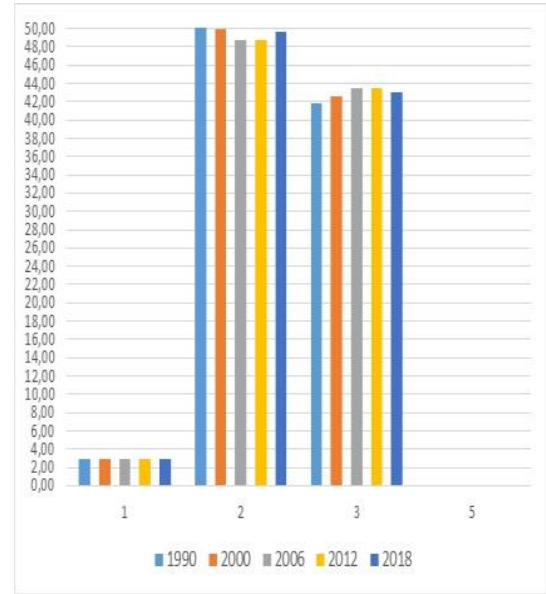

a)

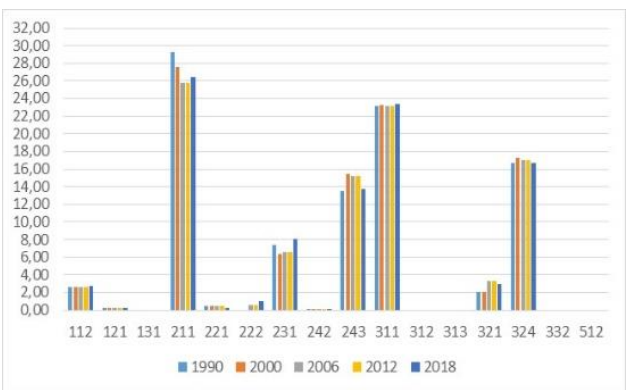

b)

Fig. 11. Land cover changes (classes, Table 1) in a group of SLUAs from the Municipality of Lovech (Lovech District) falling within the territory of the Devetashko plateau (\%): a) (Level 1); b) (Level 3)

Source: [I.1.], Elaboration: D. Stefanova, G. Jelev

\section{Lands from the Municipality of Sevlievo (Gabrovo District)}

The SLUAs from the Municipality of Sevlievo (Gabrovo District), which fall within the limits of the plateau include in whole the SLUA of Agatovo village and partially that of Kramolin village (Fig. 4). Their total area amounts to $49.12 \mathrm{~km}^{2}$ or $14.32 \%$ of the plateau's area. The population in both settlements numbers 604 people (2018). The drop with respect to 1990 (1 398 people) is $56.80 \%$ (Fig. 5).

On the SLUAs from the Municipality of Sevlievo, similar to the Municipality of Letnitsa, at level 1, the shares of Agricultural areas are significantly greater (more than 2 times) then those of Forest and semi natural areas (Fig. 12a). At this CORINE, land cover level, and insignificant changes are recorded over the years. The situation at level 3, however, is different. More essential changes take place there in both classes from level 1 .

The number of presented classes also manifests changes and difference with respect to the plateau as a whole. In 1990 and 2000, they are 12, and from 2006 to 2018, the classes are 13 (Fig. 12b). Mineral extraction sites (131) from Artificial surfaces and Coniferous forest (312) and Natural grasslands (321) from Forest and semi natural areas are permanently lacking over the entire period. In 
the beginning of the period (1990 and 2000), lack of areas of Industrial or commercial units (121) is also identified.

Non-irrigated arable land (211) demonstrates exclusively high shares, retaining relatively close values over the entire period (Fig. 12b). The other classes from level 3 of Agricultural areas, which feature significantly lower shares display-varying dynamics. Broad-leaved forest (311) is the second ranking land cover, with lasting tendency for dropping down. With Transitional woodlandshrub (324), an increase is observed after 2000, but on the overall it is exceptionally weak.

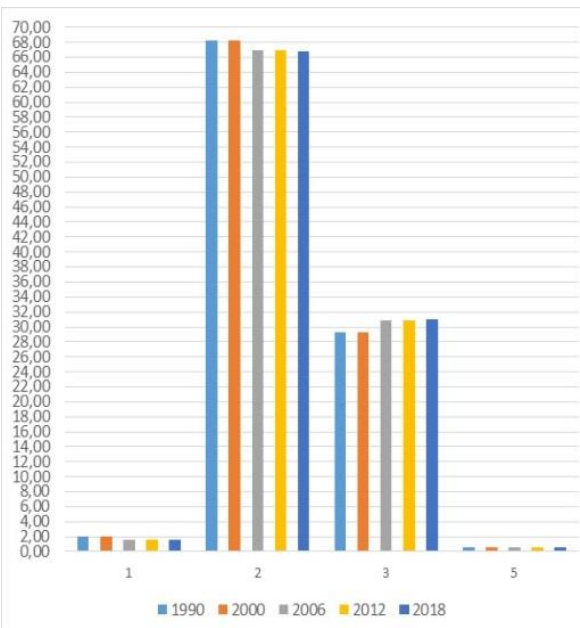

a)

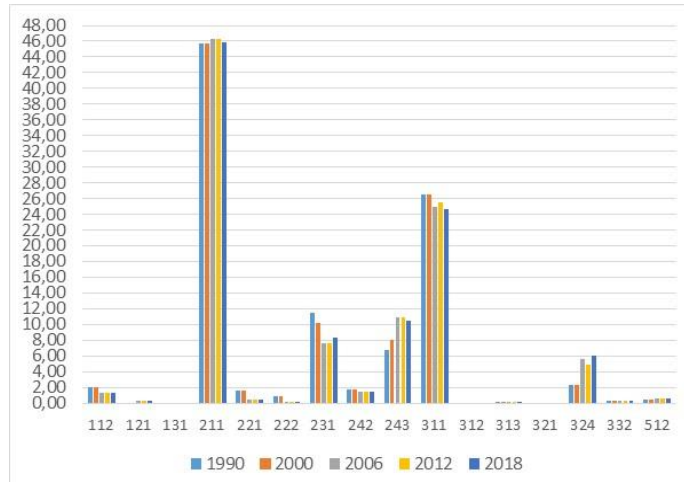

b)

Fig. 12. Land cover changes (classes, Table 1) in a group of SLUAs from the Municipality of Sevlievo (Lovech District) falling within the territory of the Devetashko plateau (\%): a) (Level 1); b) (Level 3)

Source: [I.1.], Elaboration: D. Stefanova, G. Jelev

\section{Lands from the Municipality of Pavlikeni (Veliko Tarnovo District)}

The SLUAs from the Municipality of Pavlikeni (Veliko Tarnovo District), which falls within the boundaries of the plateau, include in whole the SLUAs of Dimcha village, and in part - of Varbovka village and the town of Byala Cherkva (Fig. 4). Their total area amounts to $22.83 \mathrm{~km}^{2}$ or $6.65 \%$ of the plateau's area. The population of both settlements falling entirely within the plateau's periphery numbers 1687 people (2018). The drop with respect to 1990 (2034 people) is $17.06 \%$ (Fig. 5).

Similarly, with the SLUAs from the Municipality of Pavlikeni, as well as with those from the Municipality of Sevlievo, Agricultural areas are over twice 
greater than Forest and semi natural areas (Fig. 13a.). Over the entire observed period, they feature about $66 \%$, whereas the changes during the years are insignificant. During the first four years, Forest and semi natural areas retain constant shares of $26.70 \%$ and only in 2018 ; they increase insignificantly to $27.49 \%$.

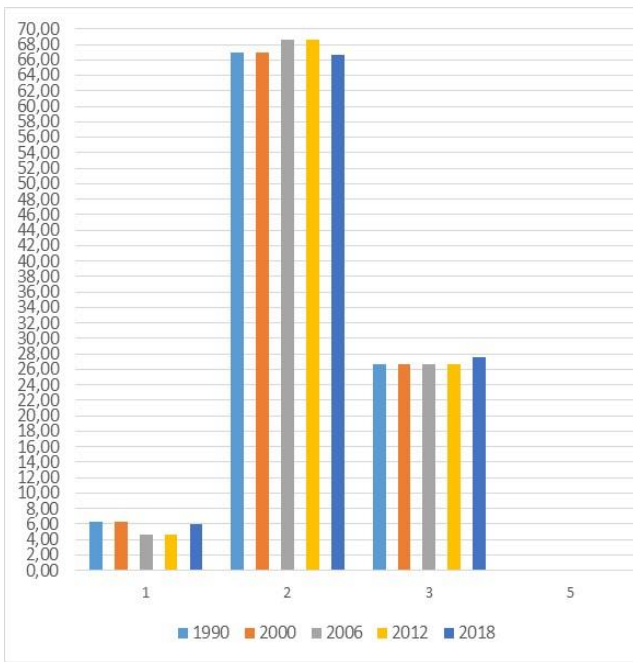

a)

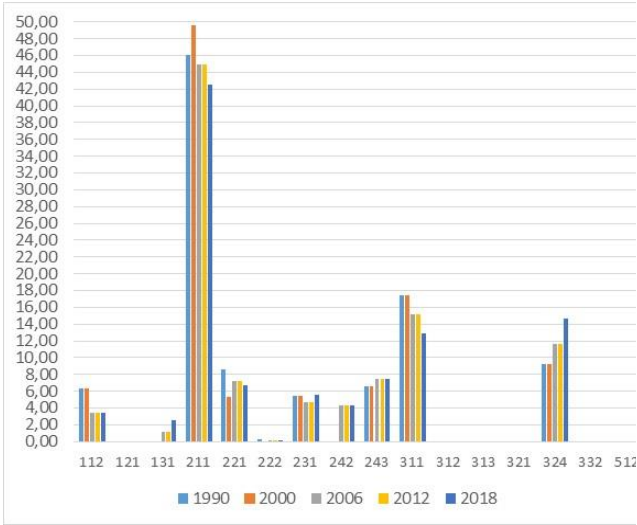

b)

Fig. 13. Land cover changes (classes, Table 1) in a group of SLUAs from the Municipality of Pavlikeni (Lovech District) falling within the territory of the Devetashko plateau (\%): a. (Level 1); b. (Level 3)

Source: [I.1.], Elaboration: D. Stefanova, G. Jelev

Over the entire observed period, six of the classes at level 3, characteristic of the whole plateau, are not present on the SLUAs of the Municipality of Pavlikeni. These are mainly classes from Forest and semi natural areas, namely, Coniferous forest (312), Mixed forest (313), Natural grasslands (321) and Bare rocks (332). No areas from the classes Industrial or commercial units (121) and Water bodies (512) are available, either.

Characteristic of this Municipality are the high shares of Non-irrigated arable land (211), which in 2000 reach $49.59 \%$, irrespective of the subsequent drop in 2018 to $42.50 \%$. The other classes from level 3 of Agricultural areas experience continuous changes in their shares. With Forest and semi natural areas and Broad-leaved forest (311), the drop is lasting, and vice versa, with Transitional woodland-shrub it displays a tendency for increase. 


\section{Lands of the Municipality of Suhindol (Veliko Tarnovo District)}

The SLUAs from the Municipality of Suhindol (Veliko Tarnovo District), which falls within the boundaries of the plateau, include in whole the SLUA of Koevci village and in part - of the town of Suhindol and Gorsko Kosovo village (Fig. 4). Their total area amounts to $59.67 \mathrm{~km}^{2}$, or $17.39 \%$ of the plateau's area. The population in both settlement numbers 1742 people for 2018. The drop with respect to 1990 (2 034 people) is $43.55 \%$.

In the SLUAs from the Municipality of Suhindol, the shares of Agricultural areas are approximately close to those of Forest and semi natural areas. This is the second municipality after Lovech, where such ratio between these two classes at level 1 is observed. The third class at level 1 , which is presented by very small shares during the whole period, is Artificial surfaces (Fig. 14a). As a tendency, with Agricultural areas, there is a decrease of shares in 2006 and maintenance of constant shares during the years afterwards. With Forest and semi natural areas, it is vice versa - increase in shares in 2006 and maintenance of constant shares during the years afterwards.

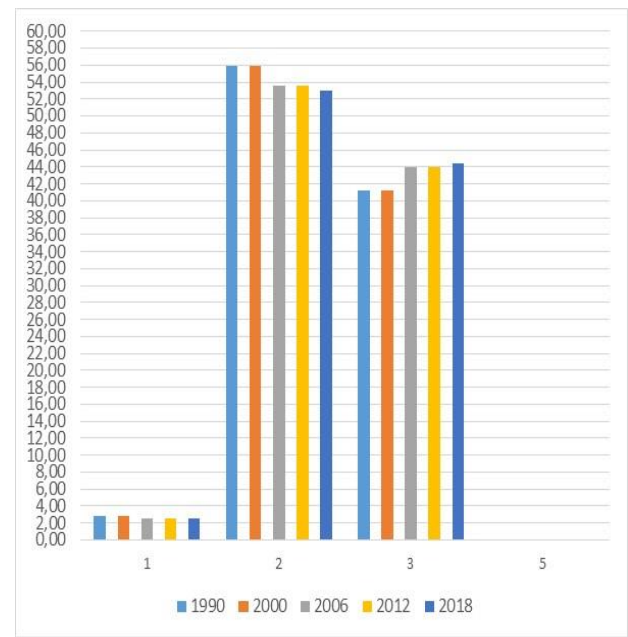

a)

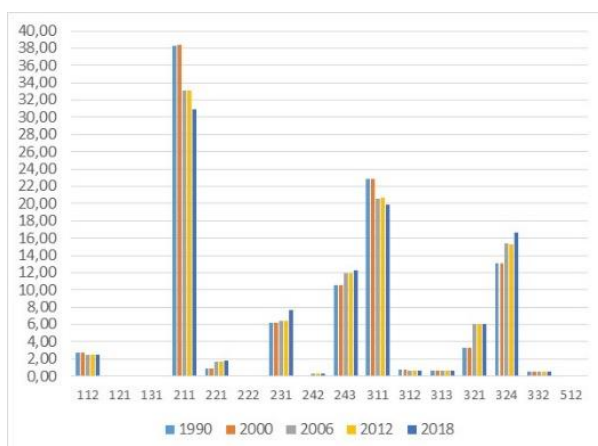

b)

Fig. 14. Land cover changes (classes, Table 1) in a group of SLUAs from the Municipality of Suhindol (Lovech District) falling within the territory of the Devetashko plateau (\%): a) (Level 1); b) (Level 3) Source: [I.1.], Elaboration: D. Stefanova, G. Jelev

The charactistic thing for the number of classes at level 3 from this subregion is the absence of one class from each class Artificial surfaces (incl. Mineral extraction sites (131), Agricultural areas (incl. Fruit trees and berry plantations (222)), and Water bodies (incl. Water bodies (512)) (Fig. 14b). 
The observation of the shares at level 3 shows that Non-irrigated arable land (211) comes first with the greatest share. Second comes Broad-leaved forest (311), followed by Transitional woodland-shrub (324). The drop with Nonirrigated arable land is accompanied by an increase in Vineyards (221), Pastures (231) and Land principally occupied by agriculture, with significant areas of natural vegetation (243). Another regularity which is observed within Forest and semi natural areas is drop of Broad-leaved forest (311) and increase in Natural grasslands (321) and Transitional woodland-shrub (324) and retaining of the values of Coniferous forest (312) and Mixed forest (313) (Fig. 14b).

\section{Change of the land cover classes}

The changes in sub-period 1990-2000 comprise 14 SLUAs from five municipalities on the territory of the Devetashko plateau with total area of $7.62 \mathrm{~km}^{2}$ (Table 2, fig. 15). For this period, eight groups of transformation of areas from one class into another at CORINE, land cover level 3 may be differentiated, most of them being the transformations in Agricultural areas.

The transformation from Non-irrigated arable land (211) into Land principally occupied by agriculture, with significant areas of natural vegetation (243) with an area of $2.41 \mathrm{~km}^{2}$ comprises the SLUAs of strongly depopulated villages and the SLUAs of Aleksandrovo village, which is outside the plateau's territory. All of them pertain to the Municipality of Lovech.

Table 2. Corine, land cover change in Model karst area "Devetashko plateau" by classes and lands for the subperiods 1990-2000, 2000-2006, 2006-2012, 2012-2018. Source: [I.1.], Elaboration: D. Stefanova, G. Jelev

\begin{tabular}{|l|c|c|}
\hline \multicolumn{3}{|c|}{ 1990-2000 } \\
\hline \multicolumn{1}{|c|}{ Total area - 7,62 km2 } \\
\hline SLUAs & CLCC & $\begin{array}{c}\text { Area } \\
\text { (km2) }\end{array}$ \\
\hline Aleksandrovo & $211-243$ & 0,00 \\
\hline Gostinya & $211-243$ & 0,00 \\
\hline Devetaki & $211-243$ & 0,71 \\
\hline Tepava & $211-243$ & 1,69 \\
\hline Varbovka & $222-211$ & 0,04 \\
\hline Dimcha & $222-211$ & 0,63 \\
\hline Suhindol & $222-211$ & 0,03 \\
\hline Dimcha & $222-211$ & 0,06 \\
\hline Gorsko Slivovo & $231-211$ & 1,89 \\
\hline Karpachevo & $231-211$ & 0,01 \\
\hline Agatovo & $231-243$ & 0,62 \\
\hline Chavdartsi & $231-243$ & 0,47 \\
\hline Brestovo & $231-324$ & 0,39 \\
\hline Tepava & $231-324$ & 0,42 \\
\hline Devetaki & $243-211$ & 0,30 \\
\hline Smochan & $243-311$ & 0,06 \\
\hline Krushuna & $311-324$ & 0,07 \\
\hline Karpachevo & $311-324$ & 0,22 \\
\hline Chavdartsi & $311-324$ & 0,01 \\
\hline & &
\end{tabular}

\begin{tabular}{|l|c|c|}
\hline \multicolumn{3}{|c|}{$\mathbf{2 0 0 0 - 2 0 0 6}$} \\
\hline \multicolumn{2}{|c|}{ Total area - 3,84 km2 } \\
\hline SLUAs & CLCC & $\begin{array}{c}\text { Area } \\
\text { (km2) }\end{array}$ \\
\hline Agatovo & $311-324$ & 0,69 \\
\hline Brestovo & $311-324$ & 0,02 \\
\hline Gostinya & $311-324$ & 0,11 \\
\hline Devetaki & $311-324$ & 0,79 \\
\hline Dimcha & $311-324$ & 0,30 \\
\hline Kramolin & $311-324$ & 0,42 \\
\hline Karpachevo & $311-324$ & 0,00 \\
\hline Suhindol & $311-324$ & 0,76 \\
\hline Tepava & $311-324$ & 0,08 \\
\hline Uaвдapци & $311-324$ & 0,01 \\
\hline Agatovo & $324-311$ & 0,09 \\
\hline Devetaki & $324-311$ & 0,26 \\
\hline Krushuna & $324-311$ & 0,07 \\
\hline Karpachevo & $324-311$ & 0,06 \\
\hline Smochan & $324-311$ & 0,03 \\
\hline Chavdartsi & $324-311$ & 0,01 \\
\hline \multicolumn{3}{|c}{} \\
& & \\
& &
\end{tabular}

\begin{tabular}{|l|c|r|}
\hline \multicolumn{3}{|c|}{$\mathbf{2 0 0 6 - 2 0 1 2}$} \\
\hline \multicolumn{2}{|c|}{ Total area - 0,88 km2 } \\
\hline SLUAs & CLCC & $\begin{array}{c}\text { Area } \\
\text { (km2) }\end{array}$ \\
\hline Kramolin & $311-324$ & 0,17 \\
\hline Kramolin & $324-311$ & 0,46 \\
\hline Suhindol & $324-311$ & 0,16 \\
\hline Koevci & $324-311$ & 0,08 \\
\hline
\end{tabular}

\begin{tabular}{|l|c|c|}
\hline \multicolumn{3}{|c|}{ 2012-2018 } \\
\hline \multicolumn{1}{|c|}{ Total area } & $-\mathbf{4 , 8 2}$ km2 \\
\hline SLus & CLCC & $\begin{array}{c}\text { Area } \\
\text { (km2) }\end{array}$ \\
\hline Gorsko Slivovo & $131-231$ & 0,26 \\
\hline Suhindol & $211-131$ & 0,09 \\
\hline Varbovka & $221-211$ & 0,11 \\
\hline Agatovo & $231-211$ & 0,21 \\
\hline Brestovo & $231-211$ & 0,07 \\
\hline Varbovka & $231-211$ & 0,29 \\
\hline Gorsko Slivovo & $231-211$ & 0,00 \\
\hline Devetaki & $231-211$ & 1,30 \\
\hline Dimcha & $231-211$ & 0,00 \\
\hline Koevci & $231-211$ & 0,41 \\
\hline Karpachevo & $231-211$ & 0,49 \\
\hline Suhindol & $231-211$ & 0,12 \\
\hline Agatovo & $311-324$ & 0,19 \\
\hline Gorsko Slivovo & $311-324$ & 0,50 \\
\hline Gostinya & $311-324$ & 0,01 \\
\hline Devetaki & $311-324$ & 0,07 \\
\hline Kramolin & $311-324$ & 0,37 \\
\hline Karpachevo & $311-324$ & 0,01 \\
\hline Suhindol & $311-324$ & 0,12 \\
\hline Tepava & $311-324$ & 0,09 \\
\hline Devetaki & $321-211$ & 0,11 \\
\hline & &
\end{tabular}


Another type of transformation during this period is from Fruit trees and berry plantations (222) into Non-irrigated arable land (211) with an area of $0.77 \mathrm{~km}^{2}$, which comprise the SLUAs from the Municipality of Pavlikeni (Varbovka and Dimcha villages) and from the Municipality of Suhindol (town of Suhindol). When the Agrarian-Industrial Complexes (AICs) were liquidated, the orchards were abandoned.

The liquidation of cattle breeding during the period 1990-2000 resulted in the transformation of pastures with an area of $4.10 \mathrm{~km}^{2}$. This process affects the SLUAs of Gorsko Slivovo and Karpachevo villages, with the transformation into Non-irrigated arable land (211), of Agatovo and Chavdartsi villages, with the transformation into Land principally occupied by agriculture, with significant areas of natural vegetation (243), and of Brestovo and Tepava villages with transformation into Transitional woodland-shrub (324).

Insignificant transformation of the area of $0.29 \mathrm{~km}^{2}$ comprises Broadleaved forest (311), which has been transformed into Transitional woodland-shrub (324) on the SLUAs of Chavdartsi, Krushuna, and Karpachevo villages.

The changes in sub-period 2000-2006 comprise 12 SLUAs from five municipalities on the territory of the Devetashko plateau with total area of $3.84 \mathrm{~km}^{2}$ (Table 2, Fig. 15). The transformations have been differentiated into two groups: the transformation of Broad-leaved forest (311) into Transitional woodland-shrub (324), which comprises the SLUAs of 10 settlements (Agatovo, Brestovo, Gostinya, Devetaki, Dimcha, Kramolin, Karpachevo, Suhindol, Tepava, and Chavdartsi villages); reverse transformation from Transitional woodland-shrub (324) into Broad-leaved forest (311) (on the SLUAs of Agatovo, Devetaki, Krushuna, Karpachevo, Smochan, and Chavdartsi villages).

Sub-period 2006-2012 comprises 3 SLUAs from two municipalities Kramolin village from the Municipality of Sevlievo and Koevci village and town of Suhindol from the Municipality of Suhindol, with total area of $0.88 \mathrm{~km}^{2}$ (Table 2, Fig. 15). The transformations are from Transitional woodland-shrub (324) into Broad-leaved forest (311) and vice versa for Kramolin village - from Broad-leaved forest (311) into Transitional woodland-shrub (324).

The last sub-period 2012-2018 comprises 12 SLUAs from five municipalities with total area of $4.82 \mathrm{~km}^{2}$ (Table 2, Fig. 15). The transformations have been differentiated into 5 groups, whereas in 2 of them the changes are more essential and comprise more SLUAs. On 9 SLUAs, Pastures (231) are transformed into Non-irrigated arable land (211), and on other 8 SLUAs - from Broad-leaved forest (311) into Transitional woodland-shrub (324).

The results from the performed analyses and the assessment of the land cover and land use of the Devetashko plateau after the CORINE nomenclature have been summarised, as follows:

- the land cover on the territory of the Devetashko plateau is presented with the greatest share by Agricultural areas, followed by Forest and semi natural 
areas, the difference between the two being about 20\%. The values of Artificial surfaces are exceptionally low and those of Water bodies are minor. At this level, the observation of the share distribution by classes displays insignificant changes, which are in the direction of increase for Forest and semi natural areas, and vice versa - decrease for Agricultural areas (Fig. 6);
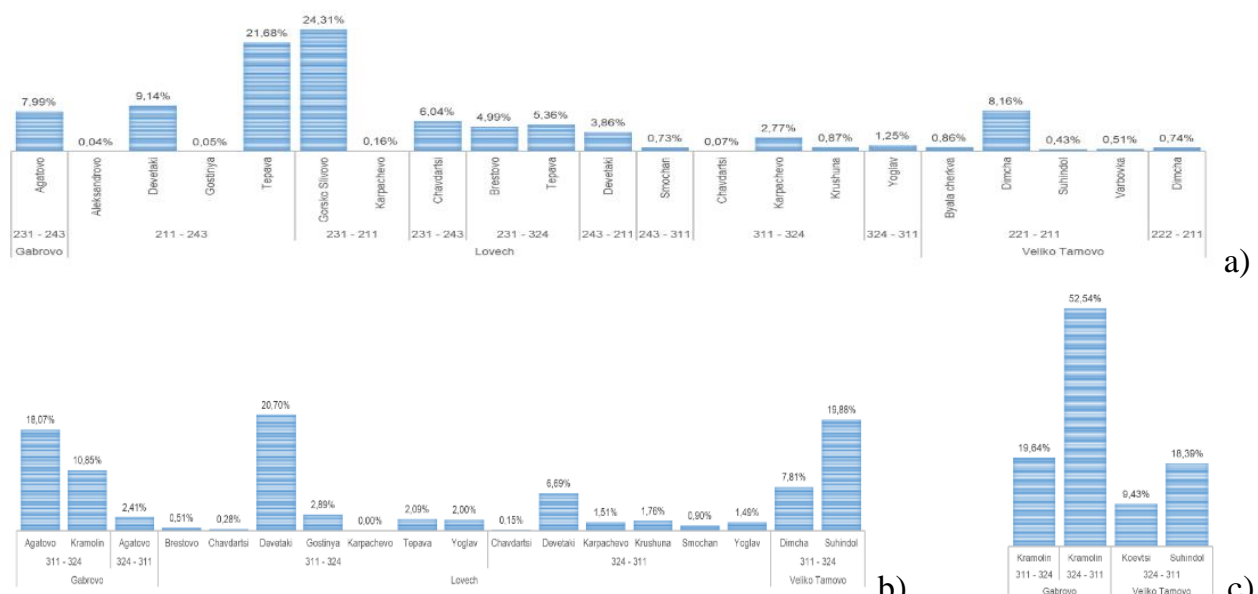

b)
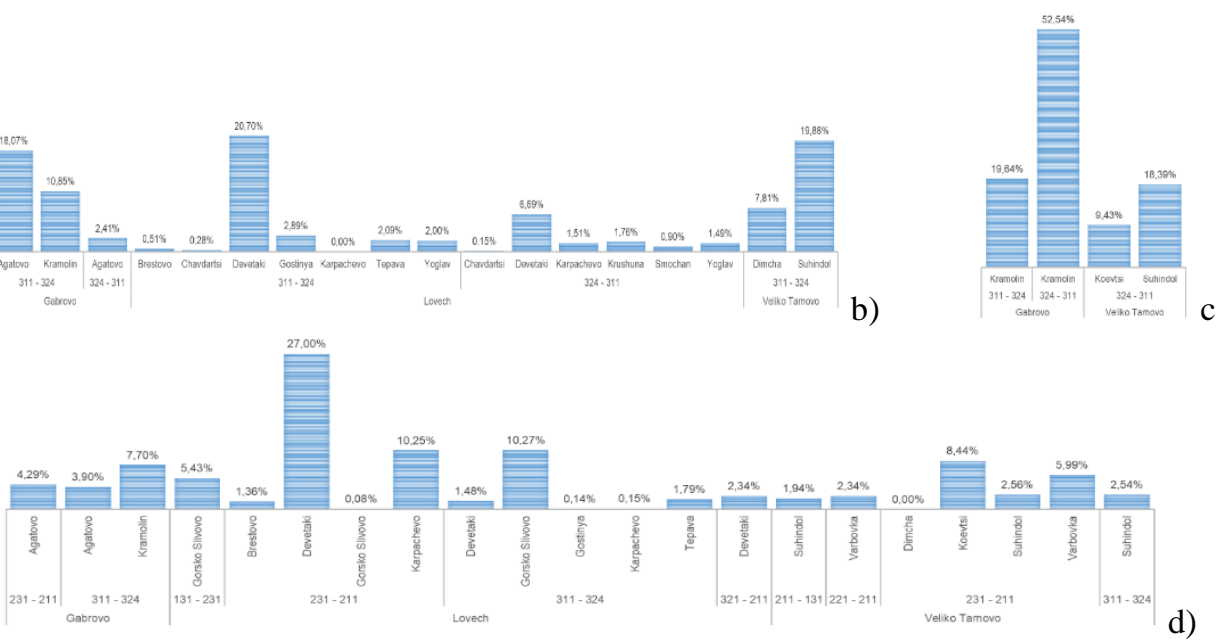

d)

Fig. 15. Corine, land cover change in Model karst area "Devetashko plateau";

a) 1990-2000, b) 2000-2006, c) 2006-2012, d) 2012-2018)

Source: [I.1.], Elaboration: Georgi Jelev

- at CORINE, land cover level 3 on the territory of the Devetashko plateau, 16 land cover and land use classes are observed. Non-irrigated arable land (211) and Broad-leaved forest (311) feature the greatest relative shares, whereas the tendency with them is for the weak decrease. Another characteristic is that the changes are mainly concentrated in classes within Agricultural areas and Forest and semi natural areas;

- over the entire period, the changes of one class into another comprise 5\% of the plateau's territory; 
- with time, the changes in land cover follow the social and economic changes in society - from the restitution of land and the liquidation of agricultural farms to provide subsidies in agriculture, which again triggered changes in the share of the individual classes of Agricultural areas. Their specific manifestation is expressed in the fact that, during the early years of the "transition“, transformation of Pastures (231), Non-irrigated arable land (211), Fruit trees and berry plantations (222) is mostly observed, resulting from collapse in cattle breeding and abandonment of arable land. A change in the areas of Broad-leaved forest (311) is also observed resulting from intensified logging. Recent years witness the reverse tendency - with the development of large-scale agriculture, pastures and natural grass areas are transformed into agricultural land;

- at the level of a group of SLUAs, located within the boundaries of territorial and administrative units (municipalities) on the territory of the Devetashko plateau, two types of combinations of land cover are observed. On three municipal lands (Letnitsa, Sevlievo, and Pavlikeni), the shares of Agricultural areas outdistance significantly (almost two-fold with respect to Forest and semi natural areas). With the other two municipalities (Lovech and Suhindol), the shares of these two classes from level 1 are approximately equal. These means that, when implementing current and future economic activities, the municipal administrations and the persons handling the lands must keep a track of the current changes and forecast the upcoming changes and possible transformations by land cover classes. But, minding the specifics of these territories, they should also comply with karst's high vulnerability to anthropogenic impacts and climatic changes.

\section{Conclusion}

The land cover and land use types and their change as a result of anthropogenic pressure or natural intervention have a strong impact on karst geosystems. Relief character and a special distribution of karst regions influence economic activity and it, on its part, influences karst geosystems.

The social and economic factor also affects land use and thence, land cover change. The pressure on karst systems is further aggravated by various conflicts of interest arising during the exercising of different economic activities, such as farming (agriculture and cattle breeding), forestry, mining, settlement development, industry, protected territories. The new circumstances of transition and continuous changes require adequate management complying with the karst specifics of the territory, among others. The absence of such management would result in serious ecological problems. In this sense, observation of land use in the highly vulnerable karst territories and the possibilities for its planning require special attention. The studies based on land cover and land use, especially in sensitive territories, such as the karst ones, may provide additional valuable information, which might improve 
land management and assist the design of strategic development policies. Because of human activity, incl. traditional agricultural activity, which prevails on the Devetashko plateau results in the transformation of karst types [17] and structural and functional changes in karst geosystems [3]. These changes, on their part, reflect, sometimes unexpectedly, on the anthropogenic activity and social environment in karst territories.

\section{Acknowledgement}

This study was funded by the research project „Current impacts of global changes on the evolution of karst (based on the integrated monitoring of model karst geosystems in Bulgaria)", Science Research Fund, Grant No. ДН14/10/20.12.2017.

\section{References}

1. Ford, D., P. Williams. Karst Hydrogeology and Geomorphology. John Wiley and Sons Ltd., 2007, $562 \mathrm{p}$.

2. Andreychuk, V., P. Stefanov. Karst geosystems and principles of protection of Karst territories. GEOgraphy’, 2006, 21, 1, 5-11. (in Bulgarian)

3. Andrejczuk, W., P. Stefanow. Podstawowe zasady ochrony krajobrazu krasowego i jaskiń. Acta Geographica Silesiana, WNoZ UŚ, Sosnowiec, 2017, 11/1, 25, 5-10 (in Polish)

4. Popov, V. Razprostranenie na karsta v B"lgarija i njakoi negovi osobenosti. Izv. Geogr.. inst., BAN, T. HIII (HHIII), Sofija, 1970, 5-19. (in Bulgarian)

5. Zapletalova, J., Stefanova, D., Vaishar, A., Stefanov, P., Dvořák, P., and Tcherkezova, E. Social development of ecologically sensitive rural areas: Case studies of the Moravian Karst (Czechia) and the Devetashko Plato (Bulgaria). Problems of Geography, 2016, 3-4, 64-84.

6. Kostova, B., R. Berberova, R. Ergina, and R. Gjurov. Rodopi - nauchno-obrazovatelen marshrut za geolozhki turiz"m, Sbornik s dokladi Osmi mezhdunaroden simpozium „Ekologija - ustojchivo razvitie 2012”. 2013, SU-Vraca. 117-127. (in Bulgarian)

7. Kostova, B., and R. Berberova. Geolozhki turiz"m po Isk"rski prolom, B"lgarija. Godishnik na departament „Prirodni nauki“. 2015, NBU, 2016, 63-70. ISSN 2367-6302 (online) (in Bulgarian)

8. Kostova, B., and R. Berberova. Geolozhki turiz"m v rajona na Karlukovo, B"lgarija. Godishnik na departament „Prirodni nauki“ 2016. NBU. 61-69. ISSN 23676302 (online) (in Bulgarian)

9. Kostova, B., R. Berberova, and R. Gjurov. Geolozhki osobenosti na Iztochnite Rodopi i vlijanieto im v"rhu njakoi kulturni aspekti. Sbornik s dokladi Mezhdunarodna nauchna konferencija „Ekologizacija 2012”. NBU. 2018, I-VII. ISBN 978-619233-048-4 (CD/DVD) (in Bulgarian) 
10. Fan, Z., J. Li, T. Yue, X. Zhou, and A. Lan. 2015. Scenarios of land cover in Karst area of Southwestern China. Environ. Earth Sci. 2015, 74, 6407-20. Springer-Verlag Berlin Heidelberg, DOI:10.1007/s12665-015-4223-z

11. Dimitrov, V., Ju. Tepeliev, R. Koleva, Ju. Krumova, N. Ilieva, T. Ljubenov, B. Borisova. 2019. Monitoring na zemnata pov"rhnost po programata „Kopernik” prez 2017-2018 g. za B"lgarija - osnovni rezultati. Proceedings of the Fifteenth International Scientific Conference SES 2019, 146-51. e-ISSN 2603-3321

12. Jakucs, Laslo 1979. Morphogenetics of karst regions, Moskva, 244-46 (in Russian)

13. Petrov, Pavel. Karstovite blata po Devetashkoto plato. Izv. b"lg. geogr. d-vo, 1933, 1, 287-91. (in Bulgarian)

14. Popov, V., P. Penchev, and L. Zjapkov. Morfologija i hidrologija na karsta v severnata chast na Predbalkana mezhdu rekite Jantra i Os"m. Izv. Geogr. inst., 1965, 9, 6991. (in Bulgarian)

15. Ninov, N. Soils. In: Geograpfy of Bulgaria, GI-BAS, „ForCom”, Sofia, 2002, 277-315. (in Bulgarian)

16. Svetlik, I., J. Mizera, P. Stefanov, and M. Lazarova: Application of radio-carbon dating in tracing land-use on karst terrains (as exemplified with the karst bog of Irmanov gyol, the Devetaki plateau, North Bulgaria). - Abstracts of the International Scientific Conference "Protected Karst Territories: Condition, Problems and Perspectives", October 2005, Shumen, 7-8.

17. Gvozdeckij, N. A. Problemy izuchenija karsta i praktika. Moskva, Mysl', 1972, 391. (in Russian)

\section{Internet sources}

I.1. Corine, Land Cover (CLC) for 1990, 2000, 2006, 2012, 2018 and Land Cover Changes (LCC) 1990-2000, 2000-2006, 2006-2012, 2012-2018. Available at https://land.copernicus.eu/pan-european/corine-land-cover [Accessed: 01 November 2019]

I.2. Informacionna sistema za zashhiteni zoni ot ekologichna mrezha Natura 2000. Available at http://natura2000.moew.government.bg/Home/Natura2000Protected Sites [Accessed: 01 November 2019] (in Bulgarian)

I.3. ASTER Global Digital Elevation Map Announcement. Available at https://asterweb.jpl.nasa.gov/gdem.asp._[Accessed: 01 November 2019] 


\title{
ПРОМЕНИ В ЗЕМНОТО ПОКРИТИЕ И ЗЕМЕПОЛЗВАНЕТО НА КАРСТОВ РАЙОН ДЕВЕТАШКОТО ПЛАТО
}

\author{
Г. Желев, Д. Стефанова, П. Стефанов
}

Резюме

Данните на CORINE Land Cover (CLC) представляват цифрови данни за земното покритие, разпределено в 44 класа, като за територията на България класовете са 36. Минималната картируема единица е 25 ha (за площни обекти) и $100 \mathrm{~m}$ за линейни обекти. Налични са набори от данни за годините 1990, 2000, 2006, 2012 и 2018 г., както и за промените настъпили между всяка двойка години (1990-2000, 2000-2006, 2006-2012 и 2012-2018).

Големият набор от данни дава възможност да се проследи за период от близо 30 години как се е променяло земното покритие в моделни карстови райони, които са силно уязвими на антропогенни и природни въздействия.

Настоящата статия разглежда промените в типовете земно покритие в Devetashko plateau - типично карстово плато в Северна България. Промените в земното покритие и в земеползването пряко влияят върху процесите на съвременния карстогенезис, почвено-растителната покривка, количеството и качеството на подземните карстови води.

${ }^{[2]}$ The settlements located on the other five lands included in the Devetashko plateau are at a great distance from the plateau and their population has not been included in the population of the plateau. The tendencies with them are the same. 